\title{
Recent Progress of Transgenic Technology Development for Alfalfa
}

\author{
Wenting Liu1, Banyar Aung², Abdelali Hannoufa ${ }^{2}$, Tim Xing ${ }^{3}$, Lining Tian ${ }^{2 *}$ \\ ${ }^{1}$ College of Life Science, Northwest A\&F University, Yangling, China \\ ${ }^{2}$ London Research and Development Center, Agriculture and Agri-Food Canada, London, Canada \\ ${ }^{3}$ Department of Biology, Carleton University, Ottawa, Canada \\ Email: *lining.tian@agr.gc.ca
}

How to cite this paper: Liu, W.T., Aung, B., Hannoufa, A., Xing, T. and Tian, L.N. (2018) Recent Progress of Transgenic Technology Development for Alfalfa. American Journal of Plant Sciences, 9, 467-482. https://doi.org/10.4236/ajps.2018.93035

Received: January 16, 2018

Accepted: February 23, 2018

Published: February 26, 2018

Copyright (c) 2018 by authors and Scientific Research Publishing Inc. This work is licensed under the Creative Commons Attribution International License (CC BY 4.0).

http://creativecommons.org/licenses/by/4.0/ cc) (i) Open Access

\begin{abstract}
Alfalfa (Medicago sativa L.) is an important leguminous crop worldwide and it has important roles in different aspects of the agriculture system, including livestock feed, crop soil conservation, and improvement of soil nitrogen supply. As a perennial crop, alfalfa breeding for trait improvement takes longer periods of time compared to many other crops, therefore, genetic engineering is a faster route for alfalfa trait modification and improvement. Alfalfa was a first crop in which somatic embryogenesis was developed. Alfalfa was also a pioneering crop in which transgenic technology was developed and applied for trait improvement. Transgenic technology in alfalfa has since advanced steadily in various areas. In this review, we update the recent research progress in alfalfa genetic engineering, focusing on genetic transformation and use of transgenic technology for trait improvement and new trait development.
\end{abstract}

\section{Keywords}

Medicago sativa, Transformation, Tissue Culture

\section{Introduction}

Alfalfa (Medicago sativa L.) is a perennial crop with a tetraploid genome [1]. Due to the high protein content that is suitable for animals, alfalfa is largely used for livestock feed. The capability of the nitrogen fixation of rhizobial bacterium associated with alfalfa is important for improvement of agriculture nitrogen balance [2]. Being of a perennial nature that covers agriculture fields all seasons, alfalfa plants play important roles in soil conservation and soil ecology [3] [4]. In addition, due to its high biomass and non-human food nature, alfalfa is an attractive crop for producing recombinant proteins and other biomaterials from plants via 
molecular farming approaches [5] [6] [7] [8]. Like many other crops, genetic engineering is an important approach for alfalfa trait modification and improvement. Development of highly efficient genetic transformation methods for different varieties is important for alfalfa genetic engineering. Alfalfa was a pioneering plant species from which somatic embryogenesis was developed [9] [10] [11]. Alfalfa was also a first crop in which genetic transformation was developed. For the past years, alfalfa biotechnology research has been steadily progressing and numerous papers have been published to report different aspects of alfalfa biotechnology development. This paper reviews the recent research progress in alfalfa genetic engineering, focusing on method development for genetic transformation and application of transgenic research. The paper reviews the topics that are not discussed in recent review papers [12] [13].

\section{Genetic Transformation-Tissue Culture Based Technology}

\subsection{Alfalfa Genotype}

Establishment of a plant in vitro regeneration system is the prerequisite for development of genetic transformation, as almost all crops including alfalfa, at this time, rely on tissue culture systems for transgenic development. Alfalfa regeneration is mainly based on somatic embryogenesis and few studies have reported regeneration of alfalfa via organogenesis. Research has indicated that alfalfa somatic embryogenesis is strongly genotype dependent compared to some other plants, and alfalfa in vitro regeneration has been reported only in very limited genotypes [14] [15] [16] [17] [18]. Given that not all the embryogenic genotypes are transformable, at this time, alfalfa transformation is limited to a few cultivars only [19]-[26]. Accordingly, lack of transformation in many alfalfa cultivars is largely due to the lack of in vitro regeneration system in these genotypes, rather than transformability of these genotypes. In this regard, development and improvement of regeneration technologies, specifically, development of somatic embryogenesis technology, is important for future research to achieve genetic transformation for a large number of alfalfa cultivars and genotypes.

\subsection{Explant Type}

Compared to many other plant species in which transformation is usually conducted using a single and specific explant, alfalfa genetic transformation can be achieved using different types of explants, such as roots, leaves, stems, petioles and somatic embryos, if the genotypes are feasible for somatic embryogenesis [24]-[34]. Specifically, if a genotype is identified to be embryogenic and regenerable, there is a good chance that somatic embryos can be induced in different types of explants. Accordingly, transformation can be conducted using different types of explants. Tian et al. [35] report genetic transformation using a number of different organs as explants and transgenic plants were recovered from all the explants tested. It appeared that the transformation efficiency was not affected by 
the explants used, rather it depended on the somatic embryogenesis capacity of the explants.

Study and exploration of alfalfa transformation using different types of explant materials not only provide options to meet different needs and situations, but can also provide possibility for a short time frame and feasibility for transfer of new genes into previously transformed alfalfa plants for multiple trait improvement. Besides using ordinary organs for explant transformation, somatic embryos derived from tissue culture can also be used for transformation in alfalfa. Use of somatic embryos as explants in alfalfa genetic transformation can be conducted via direct and indirect somatic embryogenesis [24] [27] [28] [36] [37]. In direct embryogenesis, somatic embryos were first infected by Agrobacterium. The secondary embryogenesis was induced through direct and spontaneous new embryogenesis from primary somatic embryos without callus phase. This method appeared to be effective for alfalfa transformation. However, molecular analysis, such as Southern blotting, which is essential to confirm transformation, was not conducted in recovered plants [27] [28] [37]. The concern is that selection through direct embryogenesis may be less effective and may result in escapes [27]. In addition, spontaneous embryogenesis appeared to be very genotype specific and thus the technique may be restricted to unique clones and genotypes. Liu et al. [24] report a transformation system which also used somatic embryos as explants. The system was based on cell dedifferentiation or cell reprogramming of somatic embryos induced by plant growth regulators, subsequent induction and development of embryogenic calli, and somatic embryo formation from the calli cultured on plant growth regulator-free medium. The biological and regeneration pathway of secondary embryogenesis reported by Liu et al. [24] is different from direct and repetitive embryogenesis [27] [28] [37]. The transformation reported by Liu [24] could be applied to different genotypes and no escapes were observed. Introduction of multiple genes of interest into previously transformed plants to confer plants with different traits is a direction of wide application of transgenic technology [32]. Use of somatic embryos as explants from transgenic plants to initiate transformation to introduce new genes of interest can reduce the time for development of plants that contain multiple new traits. In addition, the system may be an option for those cultivars in which use of other organs for transformation is difficult.

\subsection{Tissue Culture Method and Transformation}

Since the first report of alfalfa genetic transformation, tissue culture-based method has been the main procedure for alfalfa transformation. Nevertheless, use of other methods has also been attempted. Weeks et al. [38] report an in-planta transformation method in which the seedlings were cut at the apical meristem region and infected by Agrobacterium solution with a combination of a few other procedures. This method avoided using the tissue culture system. In-planta transformation has also been reported in Medicago truncatula which is closely related 
to alfalfa by taxonomy. In that report, seedlings or flowers were infiltrated with Agrobacterium solution and seeds produced from Agrobacterium-infected plants were harvested and then screened to select transformants [39]. In-planta transformation has a number of advantages over tissue culture-based approach; mainly it can reduce extensive labor work involved in tissue culture and avoid using tissue culture facility which is usually costly. However, few studies have since reported to adapt the in-planta transformation methods described above to alfalfa. This indicates that in-planta transformation is less effective and repeatability is low. At this time, tissue culture is still the main method for alfalfa transformation. Thus, continuous research on improving tissue culture methods is still important for alfalfa transformation development and improvement.

Based on the medium reported by Blaydes [40] and Schenk and Hildebrandt [41], Tian et al. [29] report development of a method in which embryogenic callus can be maintained for a long period of time without losing the embryogenic capacity and when in need, the callus can be transferred to an embryo development medium for embryo formation and subsequently plant recovery [29] [40] [41]. The advantages of this method concerning transformation is that the callus can be maintained for proliferation for an extended period of time and thus the selection for transgenic calli can be conducted repeatedly on fresh medium. This system can strength the selection to effectively eliminate non-transformed cells and to ensure all the tissues developed and plants recovered are all true transformants [29]. Improvement of tissue culture methods to increase the quality of somatic embryos for effective plant regeneration is an important approach to increase alfalfa transformation. Amini et al. [42] report that the efficiency of alfalfa somatic embryo development was increased to $52 \%$ in medium supplemented with natural extract from Cuscuta campestris from $26 \%$ when no natural extract was used [42]. Subsequently, alfalfa transformation efficiency was increased from $15.2 \%$ to $29.3 \%$ using the medium containing natural extract. HPLC and GC/MS analyse of the extract showed that the natural extract contained a high level of $\mathrm{ABA}$ and certain compounds that promoted somatic embryo maturation. The study suggests that alfalfa genetic transformation could be limited by inefficient tissue culture system and improvement and optimization tissue culture methods can be an important approach for improvement of transformation efficiency or even for the success of transformation.

\subsection{Selection Scheme}

Various selectable markers have been used to generate transgenic alfalfa lines [43]. Different types of markers have specific advantages and availability of different selection systems is especially useful for sequential transformation to introduce multiple traits into alfalfa plants [44] [45]. Like many plants, using non-antibiotic and non herbicide-based markers for transformation is very much desired. Furthermore, use of alfalfa plant endogenous genes for selection can avoid use of foreign markers and thus can remove some obstacles for wide application of transgenic 
technology. Ferradini et al. [34] [46] reported use of an alfalfa endogenous gene to select for alfalfa transformation. Gabaculine is an inhibitor of glutamate 1-semialdehyde and aminotransferase (GSA) is toxic to a many plants [34] [46]. A GSA gene, named MsGSAgr was isolated from alfalfa with point-mutation for gabaculine resistance and was proved to be an efficient selectable marker for alfalfa transformation [34]. Forty three percent of the explants produced somatic embryos with this new selection strategy. This selectable marker gene has also been used in distantly related species including tobacco and wheat for transformation. Because the $G S A$ gene is present in all plants, the authors suggest this endogenous plant gene may be used with similar point-mutation for transformation selection of a wide range of plant species [34] [47].

Besides markers, an important aspect of successful selection is the promoters that drive the expression of the marker genes in different tissues. This is especially true in alfalfa as transformation in alfalfa can be conducted using different types of explants. CaMV35 promoter has been widely used in plant transformation, even for a marker derived from alfalfa [34]. However, the $35 \mathrm{~S}$ promoter is virus-derived and commercial application of transgenic plants containing viral promoters or genes can have safety concerns. Tian et al. [35] used a plant constitutive promoter, tCUP [48], to drive the marker gene expression for alfalfa transformation. tCUP is a cryptic promoter found in tobacco via promoter trap strategy [35] [48]. This promoter showed constitutive expression in various tissues and different plant species. The study showed that the tCUP can direct the nptII marker expression in various organs in alfalfa and successful recovery of transgenic plants was demonstrated [48]. Use of a plant derived constitutive promoter in combination with a plant-derived selectable markers [34] for producing transgenic plants added an important merit to application of transgenic technology in alfalfa.

\subsection{Preservation of Transgenic Material and Transgene}

Preservation of transgenes and transgenic materials is an important issue for the wide application of transgenic technology after transgenic plants are generated. Transgene in plants is usually stored in seeds, and after seed germination, the gene can then pass to the next generation. Nevertheless, after self-cross, a portion (a quarter) of the seeds of F1 plants will lose the transgene due to the heterologous status of transgene in plant genome [49] [50]. Several rounds of self-crossing and generations are required to obtain homozygous plants and seeds that all contain the transgenes [51]. Transgene expression in different transgenic plants derived from different transgenic events varies dramatically due to various factors, such as copy number and insertion site. Accordingly, only a few transgenic plants can show desirable levels of transgene expression. Furthermore, the amount of seeds developed from a desired transgenic plant is handful. Development of other methods for transgene preservation is desirable.

Liu et al. [25] reported development of a new technology for stable transgene 
preservation and authentic expression of transgene in alfalfa plants. Somatic embryos were first induced from transgenic plants [25]. Somatic embryos were then treated with abscisic acid (ABA) to induce desiccation tolerance [50] [52] [53] [54] [55]. The embryos that acquired desiccation tolerance were subjected to water loss process. The dried embryos can be stored at room temperature for extended periods of time. After rehydration, the dried embryos showed high percentage of viability and exhibited routine germination. Normal plants were developed and recovered. Plants germinated from dried somatic embryos showed normal transgene expression and the gene expression levels were comparable to that of plants developed from somatic embryos without desiccation process. Because there is no transgene segregation as occurs in true seeds of F1 plants, all the embryos produced contain the transgene. This can dramatically reduce the time and labor to produce transgene homozygous plants via self-crossing. A large number of somatic embryos can also be induced from a single transgenic plant and this overcomes the limitation of only a handful amount of true seeds can be obtained from a plant. In addition, the transgenic and dried somatic embryos containing the new genes and proteins can be easily transported to other areas when needed. Dried somatic embryos or artificial seed technology provide a novel and useful method for transgene preservation. In another study by Vdovitchenko and Kuzovkina [56], “artificial seeds" were produced from genetically transformed roots of Baikal skullcap (Scutellaria baicalensis Georgi) and common rue (Ruta graveolens L.), which are medicinal plants [56]. Although authors used terminology of "artificial seeds", the transgenic materials used in artificial seeds were root fragments encapsulated in gel coat. After long-term storage at low temperature, new shoots can be induced from the artificial seeds. The new tissues developed contained high and desired levels of flavone contents. The study also described some other advantages of the technology including preservation of valuable materials, easy long distance transportation, and little microorganism infection. The method of using other parts of transgenic plants, rather than somatic embryos subjected to encapsulation as described by Vdovitchenko and Kuzovkina to preserve transgenes may be extended to alfalfa to avoid somatic embryogenesis process [56].

\section{Application of Transformation Technology}

Transgenic technology has been used for trait improvement or adding of new traits to alfalfa, and numerous studies for different attributes have been reported (see recent review [13] [57]). Besides traditional agricultural trait improvement, such as biotic and abiotic stress resistance, alfalfa has also been explored for recombinant protein production due to its high biomass production [7] [58]. As a non-human food plant, use of alfalfa transgenic plants for new protein production has less public or ethical concerns. For the past years, many genes have been transferred to alfalfa for new protein expression and production. However, commercial production of recombinant proteins using alfalfa has not been well achieved. This part of the review will discuss this issue and potential approaches 
to increase expression via tissue culture. In addition, improvement of alfalfa forage yield and quality has been challenging via traditional methods [59] [60], but has become possible via the transgenic approach and thus will be discussed here.

\subsection{Increasing Recombinant Protein Expression via Tissue Culture Approach}

Numerous new biomolecules, including proteins, enzymes, pharmaceuticals and industrial materials have been expressed in alfalfa via transgenic technology [13]. Transgenic approach has also been used to induce chemical functional groups and molecular structure changes in alfalfa [61]. However, at this time, molecular farming to express new proteins in alfalfa is still largely carried out in the laboratories and has yet to reach commercial production stage. Various factors limit the use of the technology commercially. Low level of accumulation of new proteins is indeed the most limiting factor, and thus, improvement of technologies and development of new systems that can lead to high levels of new protein expression are needed for practical application of molecular farming in alfalfa. Recombinant proteins in alfalfa plants are usually expressed in high biomass organs, such as leaves and stems. However, vegetative organs and tissues are not natural reservoirs for protein accumulation, especially for high amounts of foreign protein expression, and the new proteins in these types of organs tend to be degraded by plant regulatory enzymes [62]. Seeds are natural organs for protein accumulation and may be used for new protein production. However, the protein concentration and contents in seeds for a plant species are already high and the space is "full". In addition, seed production of alfalfa needs special pollinators, such as bees. Using bees may not be possible in some areas, which has increased difficulty of seed production.

Plant tissue culture has been recently re-studied and appears to be a potential system for high levels of recombinant protein expression via transgenic technology. Somatic embryos resemble zygotic embryos in many aspects and may accumulate higher levels of proteins as true seed. A study by Winkelmann et al. [63] showed that $74 \%$ of the proteins expressed in zygotic embryos were also found in a similar pattern to express in somatic embryos of ornamental plant Cyclamen persicum using proteomic analysis [63]. Liu et al. and Fu et al. reported somatic embryos could be used for higher levels of new protein expression [31] [64]. Three heterologous genes of uid, $c t b$, and $h I L-13$ coding for different proteins were independently transferred into alfalfa via genetic transformation. Somatic embryos were subsequently induced via tissue culture from transgenic plants carrying these genes. Expression analyses showed somatic embryos accumulated significantly higher amounts of new proteins compared to vegetative organs, such as leaves, stems and roots [31] [64]. The new proteins expressed in somatic embryos also exhibited biological activities. They proposed that somatic embryos may have extra "compartments and spaces" for large amounts of new proteins accumulation compared to true seeds in which the spaces may 
have already been filled by various proteins. Large numbers of somatic embryos can be produced using small amounts of tissues, somatic embryo production can also be scaled up many folds via bioreactors and can be standardized and industrialized. Also, the time for somatic embryo production is much faster than true seed development. Moreover, research has shown that somatic embryos can be induced in planta via regulating the express of certain genes [65] [66]. In planta somatic embryogenesis, once fully developed, can avoid tissue culture approach for embryogenesis and can reduce the cost associated with tissue culture. Thus, somatic embryos may be used as a new and efficient system for new protein production in alfalfa plants.

Other plant tissue culture systems have also been recently employed to increase recombinant protein expression. Kaldis et al. expressed ER-targeted human interleukin-10 (IL-10) in tobacco BY-2 cell suspension [67]. They reported the accumulation of hIL-10 obtained in cell suspension culture of transgenic line was the highest compared to any other stablely transgenic plant expression systems. The authors report that BY-2 cells can multiply up to 100 fold in just one week, which provides a possibility for a large-scale recombinant protein production. Somatic embryos and cell suspension culture have been established for many plant species and may be explored as alternative systems for new protein expression. Moreover, using tissue culture can confine transgenic plants without growing plants in fields. Indeed, the approved first therapeutic proteins for administration in medical treatments in humans and animals were produced in plant cell suspensions partially because the proteins were produced in contained environment. Further research to improve and optimize tissue culture can lead to development of a new system of molecular farming via plant system.

\subsection{Forage Yield and Quality Improvement}

Breeding in the early $20^{\text {th }}$ century released many alfalfa cultivars, notably "Atlantic" in 1940, "Ranger" in 1942 and "Vernal" in 1953 [68]. However, yield comparison of the varieties released in 1990s and 1950s showed no significant improvement in alfalfa breeding [59]. Improving alfalfa forage yield through traditional breeding methods appears to be restricted, in part because biomass production depends on a number of factors such as environment, growing seasons and plant genetics [59] [60].

Progress via traditional breeding aimed at improving forage quality is also limited. Generally, forage quality improvement involves increasing digestibility by reducing indigestible cell wall components, such as lignin, and enhancing nutrient composition (protein, sugar, starch, cellulose contents, etc.) in new alfalfa cultivars [26] [69]. It may not be possible to simultaneously improve all of those traits through traditional breeding methods. Functional genomics and genetics are tools to identify novel genes and molecular markers (for example, quantitative trait loci) controlling important agronomic traits in crop plants. A number of such candidate genes are now being tested to develop breeding strategies for 
forage yield and quality improvement in alfalfa [13] [26] [69] [70] [71] [72] [73]. For the past several years, transgenic technology has been rapidly developed to improve yields in cereal crops including rice [74] [75] [76], wheat [77], maize [78], barley [79], and forage crops including switchgrass [80]. Very recently using transgenic approach for alfalfa yield improvement has also been reported [70] [73]. Aung et al. demonstrated that overexpression of homologous MsmiR156 gene delayed flowering, and enhanced shoot branching and biomass production in transgenic alfalfa [73]. In addition, manipulation of heterologous LjmiR156 (a miR156 precursor from Lotus japonicus) also improved biomass production even though MsmiR156 and LjmiR156 transgenes displayed some unique effects on forage quality in transgenic alfalfa [70]. Apart from forage yield improvement, transgenic technology has also been used to enhance forage quality in alfalfa. Expression of chimeric genes encoding a ruminal stable, sulfur amino acid-rich protein from sunflower seed resulted in a significant increase in sunflower seed albumin in transgenic alfalfa leaves [81]. Lignin is a major structural polymer in plant vascular tissues, and its rigidity inhibits rumen fermentation of cell wall polysaccharides. Gene manipulation strategies have thus been developed to reduce lignin content in alfalfa. Boucher showed that down regulation of the gene encoding Cinnamyl alcohol dehydrogenases (CAD); an enzyme that catalyzes the last step in the biosynthesis of lignin precursors altered lignin composition and improved in situ cell wall degradation in transgenic alfalfa [82]. Moreover, lignin modification by down regulating hydroxycinnamoyl coenzyme A: shikimate hydroxycinnamoyl transferase (HCT) resulted in a significant increase in digestibility and lignocellulose processing ability in transgenic alfalfa [69] [83]. Aung et al. (2015a) demonstrated that high level of MsmiR156 overexpression resulted in a significant decrease in lignin and increase in cellulose contents, even though those significant effects on forage quality were not observed in the transgenic alfalfa expressing low and moderate MsmiR156 levels. Similarly, high level of LjmiR156 expression significantly increased starch, total flavonoid and total phenolic contents in transgenic alfalfa [26] [70]. These results clearly indicate that transgenic technology has a high potential to improve such agronomic traits as forage yield and quality, which are rarely achieved through traditional breeding methods in alfalfa.

\section{Conclusion}

Alfalfa is an important forage crop worldwide. Like many other crops, transgenic technology is an important approach for alfalfa trait improvement. For the past years, many studies have contributed to alfalfa transgenic technology development and advancement as well as to crop trait improvement via transgenic technology. Alfalfa is a first crop in which plant in vitro regeneration and transformation technologies were developed. Indeed, transformation in alfalfa is only available, at this time, for a few genotypes and is yet to be developed for the vast majority of varieties and genotypes. In addition, high throughput transformation me- 
thods, which are important for genomics and molecular biology research, have not been developed. As transformation in alfalfa is essentially based on in vitro regeneration, a major barrier in alfalfa transformation is that regeneration has not been developed for these plants. Continuous research in tissue culture is important for alfalfa genetic transformation and biotechnology development, which is a major discussion focus of this review. Further development of transformation methods is important for promoting the application of transgenic technology for crop trait improvement, which is yet to be seen. Genome editing, especially CRISPR-Cas, is a new and powerful technology for crop trait improvement and has been reported for many plant species but has yet to be demonstrated in alfalfa. Genome editing is usually conducted through genetic transformation. Development of a highly efficient transformation technology for different alfalfa varieties and genotypes will provide a platform for application of genome editing in alfalfa for trait and quality improvement and modification in the future.

\section{Author Contribution}

LT and WL conceived the article subject. AH and TX participated in discussion of article design. LT, WL and BA prepared draft manuscript. AH, TX and LT conducted manuscript revision and editing.

\section{Conflict of Interest}

The authors declare that there is no conflict of interest.

\section{References}

[1] Robins, J.G., Luth, D., Campbell, I.A., Bauchan, G.R., He, C.L., Viands, D.R., Hansen, J.L. and Brummer, E.C. (2007) Genetic Mapping of Biomass Production in Tetraploid Alfalfa. Crop Science, 47, 1-10. https://doi.org/10.2135/cropsci2005.11.0401

[2] Bouton, J. (2007) The Economic Benefits of Forage Improvement in the United States. Euphytica, 154, 263-270. https://doi.org/10.1007/s10681-006-9220-6

[3] Pacini, F., Molinaro, E., Castagna, M.G., Agate, L., Elisei, R., Ceccarelli, C., Lippi, F., Taddei, D., Grasso, L. and Pinchera, A. (2003) Recombinant Human Thyrotropin-Stimulated Serum Thyroglobulin Combined with Neck Ultrasonography Has the Highest Sensitivity in Monitoring Differentiated Thyroid Carcinoma. JCEM, 88, 3668-3673.

[4] Radović, J.S.D. and Markovic, J. (2009) Alfalfa-Most Important Perennial Forage Legume in Animal Husbandry. Biotechnology in Animal Husbandry, 25, 465-475. https://doi.org/10.2298/BAH0906465R

[5] Ziauddin, A., Lee, R.W.H., Lo, R., Shewen, P. and Strommer, J. (2004) Transformation of Alfalfa with a Bacterial Fusion Gene, Mannheimiahaemolytica A1 Leukotoxin50-gfp: Response with Agrobacterium tumefaciens Strains LBA4404 and C58. Plant Cell, Tissue and Organ Culture, 79, 271-278. https://doi.org/10.1007/s11240-004-4540-5

[6] Bellucci. M., De Marchis, F. and Arcioni, S. (2007) Zeolin Is a Recombinant Storage Protein That Can Be Used to Produce Value-Added Proteins in Alfalfa (Medicago sativa L.). Plant Cell, Tissue and Organ Culture, 90, 85-91. 
https://doi.org/10.1007/s11240-007-9258-8

[7] Stefanova, G., Slavov, S., Gecheff, K., Vlahova, M. and Atanassov, A. (2013) Expression of Recombinant Human Lactoferrin in Transgenic Alfalfaplants. Biologia Plantarum, 57, 457-464. https://doi.org/10.1007/s10535-013-0305-5

[8] Sun, X., Chi-Ham, C.L., Cohen-Davidyan, T., DeBen, C., Getachow, G., DePeters, E. and Bennett, A. (2015) Protein Accumulation and Rumen Stability of Wheat $\gamma$-Gliadin Fusion Proteins in Tobacco and Alfalfa. Plant Biotechnology Journal, 13, 974-982. https://doi.org/10.1111/pbi.12338

[9] Saunders, J.W. and Bingham, E.T. (1972) Production of Alfalfa Plants from callus Tissue. Plant Science, 12, 804-808.

[10] McKersie, B.D., Senaratna, T., Bowley, S., Brown, D., Krochko, J. and Bewley, J. (1989) Application of Artificial Seed Technology in the Production of Hybrid Alfalfa (Medicago sativa L.). In Vitro Cellular \& Developmental Biology-Plant, 25, 1183-1188. https://doi.org/10.1007/BF02621272

[11] McKersie, B.D. (1996) Somatic Embryogenesis and Artificial Seeds in Forage Legumes. Seed Science Research, 6, 109-126.

https://doi.org/10.1017/S0960258500003135

[12] Kumar, S. (2011) Biotechnological Advancements in Alfalfa Improvement. Journal of Applied Genetics, 52, 111-124. https://doi.org/10.1007/s13353-011-0028-2

[13] Wang, D., Khurshid, M., Sun, Z.M., Tang, X.Y., Zhou, M.L. and Wu, Y.M. (2016) Genetic Engineering of Alfalfa (Medicago sativa L.). Protein and Peptide Letters, 23, 495-502. https://doi.org/10.2174/0929866523666160314152618

[14] Brown, D.C.W. and Atanassov, A. (1985) Role of Genetic Background in Somatic Embryogenesis in Medicago. Plant Cell, Tissue and Organ Culture, 4, 111-122. https://doi.org/10.1007/BF00042269

[15] Raemakers, C.J.M., Jacobsen, E. and Visser, R.G.F. (1995) Secondary Somatic Embryogenesis and Application in Plant Breeding. Euphytica, 81, 93-107. https://doi.org/10.1007/BF00022463

[16] Raimondi, J.P., Camadro, E. and Babinec, F.J. (2001) Somatic Embryogenesis in Asparagus officinalis L. cv. Argenteuil: Interaction between Genotype, Explant Type and Growth Regulators on Callus Induction, Growth and Embryogenic Differentiation. Biocell, 25, 147-154.

[17] Bhojwani, S.S. and Dantu, P.K. (2013) Somaclonal Variation. In: Plant Tissue Culture: An Introductory Text, Springer, India, 141-154. https://doi.org/10.1007/978-81-322-1026-9_12

[18] Elmabrouk, K. and Elmeer, S. (2013) Factors Regulating Somatic Embryogenesis in Plants. In: Somatic Embryogenesis and Gene Expression, Narosa Publishing House, New Delhi, 56-81.

[19] Du, S.E.L. and Bowley, S. (1994) Effect of Plant Genotype on the Transformation of Cultivated Alfalfa (Medicago sativa) by Agrobacterium tumefaciens. Plant Cell Reports, 13, 330-334. https://doi.org/10.1007/BF00232631

[20] Desgagnes, R., Laberge, S., Allard, G., Khoudi, H., Castonguay, Y., Lapointe, J., Michaud, R. and Vezina, L.P. (1995) Genetic Transformation of Commercial Breeding Lines of Alfalfa (Medicago sativa). Plant Cell, Tissue and Organ Culture, 4, 129-140. https://doi.org/10.1007/BF00034229

[21] Fiore, M.C., Trabace, T. and Sunseri, F. (1997) High Frequency of Plant Regeneration in Sunflower from Cotyledons via Somatic Embryogenesis. Plant Cell Reports, 16, 295-298. https://doi.org/10.1007/BF01088284 
[22] Trinh, T.H., Ratet, P., Kondorosi, E., Durand, P., Kamaté, K., Bauer, P. and Kondorosi, A. (1998) Rapid and Efficient Transformation of Diploid Medicago truncatula and Medicago sativa ssp. Falcata Lines Improved in Somatic Embryogenesis. Plant Cell Reports, 17, 345-355. https://doi.org/10.1007/s002990050405

[23] Zhang, H., Huang, Q. and Su, J. (2010) Development of Alfalfa (Medicago sativa L.) Regeneration System and Agrobacterium-Mediated Genetic Transformation. Agricultural Sciences in China, 9, 170-178. https://doi.org/10.1016/S1671-2927(09)60081-X

[24] Liu, W.T., Liang, Z., Shan, C.J., Marsolais, F. and Tian, L. (2013a) Genetic Transformation and Full Recovery of Transgenic Alfalfa Plants via Secondary Somatic Embryogenesis. In Vitro Cellular Developmental Biology-Plant, 49, 17-23.

[25] Liu, W., Liang, Z., Sibbald, S., Hunter, D. and Tian, L. (2013b) Preservation and Faithful Expression of Transgene via Artificial Seeds in Alfalfa. PLOS ONE, 8, e56699. https://doi.org/10.1371/journal.pone.0056699

[26] Aung, B., Gruber, M., Amyot, L., Omari, K., Bertrand, A. and Hannoufa, A. (2015b) MicroRNA156 as a Promising Tool for Alfalfa Improvement. Plant Biotechnology Journal, 13, 779-790. https://doi.org/10.1111/pbi.12308

[27] Ninković, S., Miljuš-Djukić, J. and Nešković, M. (1995) Genetic Transformation of Alfalfa Somatic Embryos and Their Clonal Propagation through Repetitive Somatic Embryogenesis. Plant Cell, Tissue and Organ Culture, 4, 255-260. https://doi.org/10.1007/BF00029996

[28] Ninković, S., Miljuš-Djukić, J., Vinterhalter, B. and Nešković, M. (2004) Improved Transformation of Alfalfa Somatic Embryos Using a Superbinary Vector. Acta Biologica Cracoviensia Series Botanica, 46, 139-143.

[29] Tian, L., Wang, H., Wu, K., Latoszek-Green, M., Hu, M., Miki, B. and Brown, D. (2002) Efficient Recovery of Transgenic Plants through Organogenesis and Embryogenesis Using A Cryptic Promoter to Drive Marker Gene Expression. Plant Cell Reports, 20, 1181-1187. https://doi.org/10.1007/s00299-002-0459-7

[30] Samac, D.A. and Austin-Phillip, S. (2006) Alfalfa (Medicago sativa L.). Agrobacterium Protocols. In: Wang, K., Ed., Methods in Molecular Biology, Springer, Berlin, 301-311. https://doi.org/10.1385/1-59745-130-4:301

[31] Liu, W.T., Tian, L., Nie, X.N., Liang, Z.S. and He, W.J. (2011) Exogenous Protein Expression in Somatic Embryos in Alfalfa. Journal of Northwest A\&F Univesity, 39, 194-200.

[32] Liu, L., Fan, X.D., Wang, F.W., Wang, N., Dong, Y.Y., Liu, X.M., Yang, J., Wang, Y.Y. and Li, H.Y. (2013) Coexpression of $S c N H X 1$ and $S c V P$ in Transgenic Hybrids Improves Salt and Saline-Alkali Tolerance in Alfalfa (Medicago sativa L.). Journal of Plant Growth Regulation, 32, 1-8. https://doi.org/10.1007/s00344-012-9270-z

[33] Tohidfar, M., Zare, N., Jouzani, G.S. and Eftekhari, S.M. (2013) Agrobacterium-Mediated Transformation of Alfalfa (Medicago sativa) Using a Synthetic cry3A Gene to Enhance Resistance against Alfalfa Weevil. Plant Cell, Tissue and Organ Culture, 113, 227-235.

[34] Ferradini, N., Giancaspro, A., Nicolia, A., Gadaleta, A., Veronesi, F. and Rosellini, D. (2016) Efficient, Antibiotic Marker-Free Transformation of a Dicot and a Monocot Crop with Glutamate 1-Semialdehyde Aminotransferase Selectable Marker Genes. In: MacDonald, J., Kolotilin, I. and Menassa, R., Eds., Protocol Recombinant Proteins from Plants. Methods and Protocols, Springer, Berlin, 89-98.

[35] Tian, L., Wu, K., Ouellet, T., Foster, E.A., Latoszek-Green, M., Sibbald, S., Brown, D. and Miki, B. (2003) Activity of Elements from the Tobacco Cryptic Promoter, 
tCUP, in Conifer Tissues. In Vitro Cellular \& Developmental Biology_Plant, 39, 193-202. https://doi.org/10.1079/IVP2002365

[36] Shetty, K. and McKersie, B.D. (1993) Proline, Thioproline and Potassium Mediated Stimulation of Somatic Embryogenesis in Alfalfa (Medicago sativa L.). Plant Science, 88, 185-193. https://doi.org/10.1016/0168-9452(93)90090-M

[37] Uzelac, B., Zare, N., Smigocki, A. and Budimir, S. (2007) Origin and Development of Secondary Somatic Embryos in Transformed Embryogenic Cultures of Medicago sativa. Biologia Plantarum, 51, 1-6. https://doi.org/10.1007/s10535-007-0001-4

[38] Weeks, J.T., Ye, J. and Rommers C.M. (2008) Development of an in Planta Method for Transformation of Alfalfa (Medicago sativa). Transgenic Research, 17, 587-597. https://doi.org/10.1007/s11248-007-9132-9

[39] Trieu, A.T., Burleigh, S.H., Kardailsky, I.V., Maldonado-Mendoza, I.E., Versaw, W.K. and Blaylock, L.A. (2000) Transformation of Medicago truncatula via Infiltration of Seedlings or Flowering Plants with Agrobacterium. The Plant Journal, 22, 531-541. https://doi.org/10.1046/j.1365-313x.2000.00757.x

[40] Blaydes, D.F. (1966) Interaction of Kinetin and Various Inhibitors in the Growth of Soybean Tissue. Physiologia Plantarum, 9, 748-753. https://doi.org/10.1111/j.1399-3054.1966.tb07060.x

[41] Schenk, R.U. and Hildebrandt, A.C. (1972) Medium and Techniques for Induction and Growth of Monocotyledonous and Dicotyledonous Plant Cell Cultures. Canadian Journal of Botany, 50, 199-204. https://doi.org/10.1139/b72-026

[42] Amina. M., Delco, A. and Naziabad, H.S. (2016) Improvement of In Vitro Embryo Maturation, Plantlet Regeneration and Transformation Efficiency from Alfalfa (Medicago sativa L.) Somatic Embryos Using Cuscuta campestris Extract. Physiology and Molecular Biology of Plants, 22, 321-330.

[43] Han, S., Kowalczys, K., Latoszek-Green, M. and Brown, D.C.W. (2011) Agrobacterium-Mediated Genetic Transformation of Alfalfa through Somatic Embryogenesis. In: Aslam, J., Srivastava, P.S. and Sharma, M.P., Eds., Somatic Embryogenesis and Genetic Transformation in Plants, Narosa Publishing House, New Delhi, 219-250.

[44] Montague, A., Ziauddin, A., Lee, R., Ainley, W.M. and Strommer, J. (2007) High-Efficiency Phosphinothricin-Based Selection for Alfalfa Transformation. Plant Cell, Tissue and Organ Culture, 91, 29-36. https://doi.org/10.1007/s11240-007-9274-8

[45] Rosellini, D., Capomaccio, S., Ferradini, N., Sardaro, M.L.S., Nicolia, A. and Veronesi, F. (2007) Non-Antibiotic Efficient Selection for Alfalfa Genetic Engineering. Plant Cell Reports, 26, 1035-1044. https://doi.org/10.1007/s00299-007-0321-Z

[46] Ferradini, N., Nicolia, A., Capomaccio, S., Veronesi, F. and Rosellini, D. (2011) A Point Mutation in the Medicago sativa GSA Gene Provides a Novel, Efficient, Selectable Marker for Plant Genetic Engineering. Journal of Biotechnology, 156, 147-152. https://doi.org/10.1016/j.jbiotec.2011.08.015

[47] Giancaspro, A., Rosellini, D., Blanco, A. and Gadaleta, A. (2012) Gabaculine Selection Using Bacterial and Plant Marker Genes (GSA-AT) in Durum Wheat Transformation. Plant Cell, Tissue and Organ Culture (PCTOC), 109, 447-455. https://doi.org/10.1007/s11240-011-0109-2

[48] Foster, E., Hattori, J., Labbe, H., Ouellet, T., Fobert, P., James, L. and Miki, B. (1999) A Tobacco Cryptic Constitutive Promoter, tCUP, Revealed by T-DNA Tagging. Plant Molecular Biology, 16, 45-55. https://doi.org/10.1023/A:1006229501860

[49] Bennetzen, J.L., Springer, P.S., Cresse, A.D. and Hendrickx, M. (1993) Specificity and Regulation of the Mutator Transposable Element System in Maize. Critical Re- 
views in Plant Sciences, 12, 57-95. https://doi.org/10.1080/07352689309382356

[50] Qiao, H., Wang, F., Zhao, L., Zhou, J. and Lai, Z. (2004) The F-Box Protein AhSLF-S $_{2}$ Controls The Pollen Function of S-RNase-Based Self-Incompatibility. The Plant Cell, 16, 2307-2322. https://doi.org/10.1105/tpc.104.024919

[51] Bavage, A.D., Buck, E., Dale, P., Moyes, C. and Senior, I. (2002) Analysis of a Backcross Population from a Multi-Copy Transgenic Brassica napus Line. Euphytica, 124, 333-340. https://doi.org/10.1023/A:1015799901176

[52] Senaranta, T., McKersie, B.D. and Bowley, S.R. (1989) Desiccation Tolerance of Alfalfa (Medicago sativa L.) Somatic Embroys. Influence of Abscisic Acid, Stress Pretreatments and Drying Rates. Plant Science, 65, 253-259. https://doi.org/10.1016/0168-9452(89)90072-1

[53] Senaranta, T., McKersie, B.D. and Bowley, S.R. (1990) Artificial Seeds of Alfalfa (Medicago sativa L.). Induction of Desiceation Tolerance in Somatic Embryos. In Vitro Cellular and Developmental Biology, 26, 85-90. https://doi.org/10.1007/BF02624160

[54] Anandarajah, K. and McKersie, B.D. (1990) Manipulating the Desiccation Toleranceand Vigor of Dry Somatic Embryos of Medicago sativa L. with Sucrose, Heat Shockand Abscisic Acid. Plant Cell Report, 9, 451-455. https://doi.org/10.1007/BF00232271

[55] Hoshino, T. and Cuello, J.L. (2005) Environmental Design Considerations for Somatic Embryogenesis. In: Mujib, A. and Samaj, J., Eds., Somatic Embryogenesis, Springer, Berlin, 25-34.

[56] Vdovitchenko, M.Y. and Kuzovkina, I.N. (2011) Artificial Seed Preparation as the Efficient Method for Storage and Production of Healthy Cultured Roots of Medicinal Plants. Russian Journal of Plant Physiology, 58, 524. https://doi.org/10.1134/S1021443711030174

[57] Zhang, W.J. and Wang, T. (2014) Enhanced Salt Tolerance of Alfalfa (Medicago sativa) by rstB Gene Transformation. Plant Science, 11, 1-21.

[58] Sim, S., Weinberg, D.E., Fuchs, G., Choi, K., Chung, J. and Wolin, S.L. (2009) The Subcellular Distribution of an RNA Quality Control Protein, the Ro Autoantigen, Is Regulated by Noncoding Y RNA Binding. Molecular Biology of the Cell, 20, 1555-1564. https://doi.org/10.1091/mbc.E08-11-1094

[59] Volenec, J.J., Cunningham, S.M., Haagenson, D.M., Berg, W.K., Joern, B.C. and Wiersma, D.W. (2002) Physiological Genetics of Alfalfa Improvement: Past Failures, Future Prospects. Field Crops Research, 75, 97-110. https://doi.org/10.1016/S0378-4290(02)00020-5

[60] Lamb, J.F.S., Sheaffer, C.C., Rhodes, L.H., Mark Sulc, R., Underander, D.J. and Brummer, E.C. (2006) Five Decades of Alfalfa Cultivar Improvement: Impact on Forage Yield, Persistence, and Nutritive Value. Crop Science, 46, 902-909. https://doi.org/10.2135/cropsci2005.08-0236

[61] Heendeniya, R.G. and Yu, P. (2017) Gene-Transformation-Induced Changes in Chemical Functional Group Features and Molecular Structure Conformation in Alfalfa Plants Co-Expressing Lc-bHLH and C1-MYB Transcriptive Flavanoid Regulatory Genes: Effects of Single-Gene and Two-Gene Insertion. International Journal of Molecular Sciences, 18, 664.

[62] Arcalis, E., Stadlmann, J., Rademacher, T., Marcel, S., Sack, M., Altmann, F. and Stoger, E. (2013) Plant Species and Organ Influence The Structure and Subcellular Localization of Recombinant Glycoproteins. Plant Molecular Biology, 83, 105-117. https://doi.org/10.1007/s11103-013-0049-9 
[63] Winkelmann, T., Heintz, D., Van Dorsselaer, A., Serek, M. and Braun, H.P. (2006) Proteomic Analyses of Somatic and Zygotic Embryos of Cyclamen persicum Mill. Reveal New Insights into Seed and Germination Physiology. Planta, 224, 508-519.

[64] Fu, G., Grbic, V., Ma, S. and Tian, L. (2015) Evaluation of Somatic Embryos of Alfalfa for Recombinant Protein Expression. Plant Cell Reports, 34, 211-221. https://doi.org/10.1007/s00299-014-1700-x

[65] Chanvivattana, Y., Bishopp, A., Schubert, D., Stock, C., Moon, Y.H., Sung, Z.R. and Goodrich, J. (2004) Interaction of Polycomb-Group Proteins Controlling Flowering in Arabidopsis. Development, 131, 5263-5276. https://doi.org/10.1242/dev.01400

[66] Schubert, S., Dalhoff, A., Stress, H. and Ullmann, U. (2005) Pharmacodynamics of Moxifloxacin and Levofoxacin Simulating Human Serum and Lung Concentrations. Infection, 33, 15-21. https://doi.org/10.1007/s15010-005-8203-1

[67] Kaldis, A., Ahmad, A., Reid, A., McGarvey, B., Brandle, J., Ma, S., Jevnikar, A., Kohalmi, S.E. and Menassa, R. (2013) High-Level Production of Human Interleukin-10 Fusions in Tobacco Cell Suspension Cultures. Plant Biotechnology Journal, 11, 535-545. https://doi.org/10.1111/pbi.12041

[68] Barnes, D.K., Bingham, E.T., Murphy, R.P., Hunt, O.J., Beard, D.F., Skrdla, W.H. and Teuber, L.R. (1977) Alfalfa Germplasm in the United States: Genetic Vulnerability, Use, Improvement, and Maintenance. USDA Technical Bulletin, No. 1571.

[69] Gallego-Giraldo, L., Bhattarai, K., Pislariu, C.I., Nakashima, J., Jikumaru, Y., Kamiya, Y., Udvardi, M.K., Monteros, M.J. and Dixon, R.A. (2014) Lignin Modification Leads to Increased Nodule Numbers in Alfalfa. Plant Physiology, 164, 1139-1150. https://doi.org/10.1104/pp.113.232421

[70] Aung, B., Gruber, M., Amyot, L., Omari, K., Bertrand, A. and Hannoufa, A. (2015a) Ectopic Expression of LjmiR156 Delays Flowering, Enhances Shoot Branching, and Improves Forage Quality in Alfalfa. Plant Biotechnology Reports, 9, 1-15.

[71] Jia, B., Sun, M., Sun, X., Li, R., Wang, Z., Wu, J. and Zhu, Y. (2016) Overexpression of GsGSTU13 and SCMRP in Medicago sativa Confers Increased Salt-Alkaline Tolerance and Methionine Content. Physiologia Plantarum, 156, 176-189.

[72] Marita, J.M., Rancour, D., Hatfield, R. and Weimer, P. (2016) Impact of Expressing p-Coumaryl Transferase in Medicago sativa L. on Cell Wall Chemistry and Digestibility. American Journal of Plant Sciences, 7, 2553-2569. https://doi.org/10.4236/ajps.2016.717221

[73] Aung, B., Gao, R., Gruber, M.Y., Yuan, Z.C., Sumarah, M. and Hannoufa, A. (2017) MsmiR156 Affects Global Gene Expression and Promotes Root Regenerative Capacity and Nitrogen Fixation Activity in Alfalfa. Transgenic Research, 26, 541-557. https://doi.org/10.1007/s11248-017-0024-3

[74] Bajaj, S. and Mohanty, A. (2005) Recent Advances in Rice Biotechnology-Towards Genetically Superior Transgenic Rice. Plant Biotechnology Journal, 3, 275-307. https://doi.org/10.1111/j.1467-7652.2005.00130.x

[75] Jiao, Y., Wang, Y., Xue, D., Wang, J., Yan, M., Liu, G., Dong, G., Zeng, D., Lu, Z., Zhu, X., Qian, Q. and Li, J. (2010) Regulation of OsSPL14 by OsmiR156 Defines Ideal Plant Architecture in Rice. Nature Genetics, 42, 541-544. https://doi.org/10.1038/ng.591

[76] Wang, S., Wu, K., Yuan, Q., Liu, X., Liu, Z., Lin, X., Zeng, R., Zhu, H., Dong, G., Qian, Q., Zhang, G. and Fu, X. (2012) Control of Grain Size, Shape and Quality by OsSPL16 in Rice. Nature Genetics, 44, 950-954. https://doi.org/10.1038/ng.2327

[77] Yadav, D., Shavrukov, Y., Bazanova, N., Chirkova, L., Borisjuk, N., Kovalchuk, N., Ismagul, A., Parent, B., Langridge, P., Hrmova. M. and Lopato, S. (2015) Constitu- 
tive Overexpression of the TaNF-YB4 Gene in Transgenic Wheat Significantly Improves Grain Yield. Journal of Experimental Botany, 6, 6635-6650.

https://doi.org/10.1093/jxb/erv370

[78] Hannah, L.C., Futch, B., Bing, J., Shaw, J.R., Boehlein, S., Stewart, J.D., Beiriger, R., Georgelis, N. and Greeneb, T. (2012) A shrunken-2 Transgene Increases Maize Yield by Acting in Maternal Tissues to Increase the Frequency of Seed Development. The Plant Cell, 24, 2352-2363. https://doi.org/10.1105/tpc.112.100602

[79] Schilling, R.K., Marschner, P., Shavrukov, Y., Berger, B., Tester, M., Roy, S.J. and Plett, D.C. (2014) Expression of the Arabidopsis Vacuolar $\mathrm{H}^{+}$-Pyrophosphatase Gene $(A V P 1)$ Improves the Shoot Biomass of Transgenic Barley and Increases Grain Yield in a Saline Field. Plant Biotechnology Journal, 12, 378-386. https://doi.org/10.1111/pbi.12145

[80] Fu, C., Sunkar, R., Zhou, C., Shen, H., Zhang, J.Y., Matts, J., Wolf, J., Mann, D.G., Stewart Jr., CN., Tang, Y. and Wang, Z.Y. (2012) Overexpression of miR156 in Switchgrass (Panicum virgatum L.) Results in Various Morphological Alterations and Leads to Improved Biomass Production. Plant Biotechnology Journal, 10, 443-452. https://doi.org/10.1111/j.1467-7652.2011.00677.x

[81] Tabe, L.M., Wardley-Richardson, T., Ceriotti, A., Aryan, A., McNabb, W., Moore, A. and Higgins, T.J. (1995) A Biotechnological Approach to Improving the Nutritive Value of Alfalfa. Journal of Animal Science, 73, 2752-2759. https://doi.org/10.2527/1995.7392752x

[82] Baucher, M., Bernard-Vailhe, M.A., Chabbert, B., Besle, J.M., Opsomer, C., Montagu, M.V. and Botterman, J. (1999) Down-Regulation of Cinnamyl Alcohol Dehydrogenase in Transgenic Alfalfa (Medicago sativa L.) and the Effect on Lignin Composition and Digestibility. Plant Molecular Biology, 39, 437-447. https://doi.org/10.1023/A:1006182925584

[83] Samac, D.A., Bucciarelli, B., Miller, S.S., Yang, S.S., O’Rourke, J.A., Shin, S. and Vance, C.P. (2015) Transgene Silencing of Sucrose Synthase in Alfalfa (Medicago sativa L.) Stem Vascular Tissue Suggests a Role for Invertase in Cell Wall Cellulose Synthesis. BMC Plant Biology, 15, 283. https://doi.org/10.1186/s12870-015-0649-4 